Nisan 2020 Cilt:12 Sayı:2 (27) / April-2020 Volume:12 Issue:2 (27) Sayfa: 193-208

\title{
SÛFÎ HİKAYELERİNDE (MENKIBELERİNDE) KADIN TASAVVURU
}

\section{Hatice Çubukcu*}

\section{$\ddot{\mathbf{O z}}$}

Sûfîlerin halkın eğitiminde kullandıkları sûfî hikayelerinin, toplum üzerindeki etkisi yadsınamaz. Bu hikayelerdeki kadın tasviri sûfîlerin kadın algısını tespitte önemli bir ölçektir. Aynı zamanda sözkonusu hikayeler anlatılageldiği toplumların kadın algısını da şekillendirmektedir. Sûfî menkıbelerinde bahsedilen hanımlar; kimliği tespit edilmiş tarihî şahsiyetler olabileceği gibi isimsiz hikaye kahramanları şeklinde de olabilmektedir. Menkıbelerin geneli düşünüldüğünde hanım sûfiler hakkında olumlu bir dil kullanıldı̆̆ 1 görülür. Öyle ki bu hanımlar, tasavvuf tarihinin önde gelen erkek sûfîleriyle diyaloglarında onlara üstün gelecek tarzda ifadeler kullanmış, takvâ ve zühd hususundaki iddialarını ortaya koymuştur. Hatta onların üstünlükleri bizzat erkek sûfîler tarafından dile getirilmiştir. Bununla birlikte nasihat amaçlı hayalî kadın kahramanların zikredildiği hikayelerde kadın, insanın karanlık tarafını temsil eden nefsin sembolü olarak kullanılmıştır. Sembolizmde önemli olan mânâdır ve bu şekil hikayelerden kadının aşağılandığı sonucunu çıkarmak sembol dilinin mantığını kavrayamamaktan kaynaklanır. İslâm tasavvufunda nefs, kişinin eğitilebilen tarafıdır ve Yûsuf ile Züleyhâ hikayesinde olduğu gibi nefsin tekâmülü de kadın kahramanlar vasıtasıyla anlatılmıştır. Leylâ ile Mecnûn hikayesinde kadın, kişiyi İlahî olana ulaştıran bir vasıta olarak işlenmiştir. Zira kadın aynı zamanda mutlak güzelliğin bu âlemdeki yansımasıdır. Ayrıca, "kendini (nefsini) bilen Rabbini bilir" düsturunca kişinin kendini tanımada; kadının erkeğe, erkeğin de kadına aracılık etmesi gerekir.

AnahtarKelimeler: Menkıbe, Sûfî, Kadın, Nefis, Sembol

\section{DEPICTION OF WOMAN IN SUFI STORIES (SAGAS)}

\begin{abstract}
The sufi stories used by the sufis in public education have a considerable impact on society. The depiction of women in these stories is an important criterion for determining the perception of the sufis regarding women. At the same time, these stories shape the societies' perception of women in which they are told. The women mentioned in the sufi sagas can be historical figures whose identities are known, as well as anonymous story heroes. When the sagas are considered in general, it is seen that a positive language is used about female sufis. So much so that these ladies used very dominating statements in their dialogues with the prominent male sufis in the history of sufism and put forward their claims about taqwa and zuhd. Even, their superiority was admitted by male sufis themselves. However, in advice-oriented stories where imaginary heroines are mentioned, the woman is used as the symbol of the nafs, which
\end{abstract}

Article Types / Makale Türü: ResearchArticle / Araştırma Makalesi

Received / Makale Geliş Tarihi: 09.02.2020,Accepted / Kabul Tarihi: 26.04.2020

DOI: https://doi.org/10.26791/sarkiat.686855

* Ordu Üniversitesi İlahiyat Fakültesi, Tasavvuf Ana Bilim Dalı, haticecubukcu@odu.edu.tr ORCID ID: https://orcid.org/0000-0003-2580-4120 
represents the dark side of the human soul. Meaning is important in symbolism, and interpreting that the woman is humiliated in such stories results from the inability to grasp the logic of the symbolic language. In the Islamic sufism, the nafs is the trainable side of the person, and the evolution of the nafs is explained through heroines, as in the story of Joseph and Zuleika. In the story of Leylâ and Mecnûn, the woman is depicted as a means of reaching the Divine for a person. Because the woman is also the reflection of the absolute beauty onto this realm. In addition, in line with the motto, "he who knows himself (nafs) knows his Creator", in knowing one's self, the woman must be the mediator for the man and vice versa.

Keywords: Saga, Sufi, Woman, Nafs, Symbol

\section{GíRiş}

Çalışmanın amacı; sûfî hikayelerinden hareketle, sûfîlerin kadın algısını ortaya koymaktır. Sûfî hanımlardan bahseden tabakât kitapları sınırlıdır. Bununla birlikte mevcut eserler, sûfî hanımların biyografilerini menkıbevî bir tarzda anlatır. Sıfatü'sSafve, Nefahâtü'l-üns gibi sûfî tabakât kitaplarında hanım velîlerin çoğunun doğum ve vefât tarihleri yer almaz, ağırlıklı olarak görüștükleri sûfîlerle olan diyaloglarından, özlü sözlerinden ve kerametlerinden bahsedilir. Tarihî kişiliklerinde şüphe olmayan bu hanımlar, efsanevî karakterler olarak karşımıza çıkar. Menkıbelerde tarihî kişiliği sabit hanımlar dışında çok sayıda isimsiz kadın hikayeleri de yer alır. Kadın velîleri konu edinen menâkıb kitapları, sözlü kültürün zamanla yazıya aktarılmış şeklidir ve halk muhayyilesini, toplumun algısını yansıtması bakımından önem arz etmektedir. Söz konusu menkıbelerden hareketle dönemin kadın tasavvurunu tespit etmek tek başına yeterli delil sayılmasa da yardımcı bir faktör olarak meseleyi anlamada fayda sağlayacaktır. Şüphesiz menkıbelerin tarihî değeri tartışılan bir mevzuudur. Menkıbelere değer atfetmeyen genel kabulün aksine; Fuad Köprülü, Zeki Velidi Togan, Abdülbâki Gölpınarlı gibi araştırmacılara göre menkıbeler, diğer tarihî verilerle beraber değerlendirilebilecek kıymetli malzemelerdir. (Şahin, 2004, 29/113) Yazıldığı dönemin kültür hayatını, sosyal yaşamını aktaran hikayeler adeta, geçmişten günümüze gelen film sahneleri gibidir. Filmlerdeki olayların çoğu gerçek olmasa da filmler çekildiği dönemin kıyafetlerini, mekanlarını, insan ilişkilerini kısacası kültür hayatını, folklorunu büyük ölçüde yansıtır. Filmler nasıl sanat eseri ise menkıbeler de edebî eserlerdir ve çok yönlü araştırma konusu olabilecek malzemeye sahiptirler. Çoğunun bir mesajı vardır. Muhatabını adım adım hedeflediği neticeye götüren bu yapıtlar, olanı aktarmanın yanında, olması gerekeni de anlatır. Zirâ menkıbeler İslâm tarihinde nasihat amaçlı kullanılan yöntemlerden biridir ve onlarda idealize edilmiş kadın modellerinin yer alması doğaldır. Öyle ki, kadın velîlerin faziletinden bahseden menkıbeler, "tasavvufta ideal bir kadın velî nasıl olmalıdır?" sorusunun cevabının bulunacağı malzemelerdir, denilebilir. Bu sebepten sûfî menkıbelerinde ağırlıklı olarak kadın hususunda olumlu bir dil kullanılmış, kadın velîler yüceltilmiş̧tir. Hatta yer yer erkek sûfîlerden dahi üstün gösterilmişlerdir. Menkıbeler bu haliyle İslâmî disiplinler içinde tasavvufun, kadın hususunda daha pozitif bir yaklaşıma sahip olduğu görüşünü desteklemektedir.

Şüphesiz menkıbelerde sadece olumlu kadın imajı yer almaz. Erkeği doğru yoldan alıkoyan, şeytânî karekterde kadınları konu eden menkıbeler de azımsanmayacak ölçüdedir. Kur'an-1 Kerim'deki Yûsuf ile Züleyhâ kıssasından hareketle sûfîler kadını, nefsin sembolü olarak da nitelendirmişlerdir. Nitekim ayette; "Kadınlar, oğullar, yük yük altın ve gümüş, salma atlar, davarlar ve ekinler gibi nefsin şiddetle arzuladığı şeyler insana süslü gösterildi. Bunlar, dünya hayatının geçimliğidir. Oysa asıl varılacak güzel 
yer ancak Allah'ın katındadır" (Âl-i İmrân 3/ 14) buyrularak nefsin kadına olan meyli vurgulanmıştır. Bahsi geçen tehlikeye dikkat çeken ve erkek açısından kadını değerlendiren menkıbeler belli bir şahsı konu edinmez. Bunlar daha ziyade kahramanı meçhul, nasihat amaçlı, edebî formda yazılmış halk hikayeleridir ve bu çeşit menkıbelerde sembolik dil hakimdir. Sembolik anlatım; tasavvufî hakikatlerin dile getirilmesinde oldukça uygun bir yöntemdir. Zira sembolizmde meseleler daha basit bir dille anlatılmış olur, sembolizmin içerdiği çok katlı anlam sayesinde de insanın kademe kademe öğrenmesi sağlanır, her anlayış seviyesindeki insan onda kendine uygun bilgiler bulur. Bununla birlikte hakikat henüz onu kavrayacak seviyede olmayan kişilerden, bu yolla saklanır.

Menkıbeleri değerlendirirken dikkat edilmesi gereken en önemli husus sahip olduğu sembolik dili doğru çözümleyebilmektir. Aksi takdirde kerametlerin ağırlıkta olduğu sûfî menkıbelerindeki, sembolik anlatımın özellikleri göz ardı edilirse, menkıbeler muhatabından değer görmez ve ciddiye alınmaz. Eric Fromm'a göre sembol dili insanlığın geliştirdiği evrensel bir dildir. Mitoslarda geçmiş zaman bilgelikleri, bu dil aracılığıyla aktarılır. Sembol dili çözülmediğinde, kutsal kitaplardaki hikayelere yüzeysel bir ilgi gösterilir. Bunların dışındaki hikayeler ise "henüz aydınlığa ulaşmamış beyinlerin çocuksu ifadeleri" olarak görülür. Mitoslara, bilim öncesi aklın basit ürünleri olarak bakılır ve kestirme yoldan gidilip "saçma" şeklinde yaftalanır. Oysa ki, uzay ve zaman koordinatlarının egemen olduğu dünyada mümkün olmayacak dramatik olayların mitoslarda gerçekleşmesi sembol dilinin mantığından kaynaklanır. Bu mantıkta önemli olan mekan ve zaman değil; yoğunluk, anlam ve çağrışımdır. (Fromm, 1992, 18, 21) Dolayısıyla sûfî hikayelerinde kadın velîlerin yaşadıkları olağanüstü halleri ve kadının nefsin remzi olarak kullanılmasını sembol dilinin kendine has özellikleri çerçevesinde değerlendirmek gerekir. Aksi halde kadının nefs şeklinde nitelendirilmesi, kadının aşă̆ılanması olarak algılanabilir ki bu yüzeysel ve kolaycı bir değerlendirme tarzıdır.

Yukarıda da değinildiği üzere menkıbe olarak adlandırılan hikayecilik usûlu sûfîler için etkili bir tebliğ ve tanıtım yöntemidir. Hikayedeki idealize edilmiş kahramanlar sayesinde velî yani insan-1 kâmil anlayışı ortaya konur, insanlar onlar gibi olmaya yönlendirilir. Menkıbeler, tebliğ için en uygun yöntemlerden biridir. Nitekim mesajın hikaye formunda verilmesi karşı tarafın savunmasını kırar, hikayeler vasıtasıyla sezdirilen ince hikmetler, nefsanî savunma mekanizmasını tetikleyip alarma geçirmez. Rasyonel akıl, kıssalarla gizlice gelen meydan okumayı pek sezemez, bu yüzden direnç gösteremez. (Goleman, 2019, 12) Menkıbeler bilgi yanında duyguyu da aktardığı, soyut mevzuları somutlaştırdığı için muhatabında daha etkili ve kalıcı öğrenme sağlar. Mesajın edebî formda verilmesi hitap edilen kitleyi çeşitlendirir ve bu yolla daha çok kişiye ulaşılır. Bu hususta Mevlânâ'nın Mesnevî'si çarpıcı bir örnektir, zira müslüman, gayri müslim, avâm, havâs, dindar, dine mesafeli her kesimden insana ulaşmayı başarmış bir eserdir. Toplumda sürekli tekrar edilen menkıbeler sayesinde o toplumların ortak hafızaları meydana gelir. Örneğin, Anadolu'da helal lokmanın önemi halkın bilincine İmâm-1 Âzam'ın babasına atfedilen suya düşen elma hikayesiyle kodlanmıştır, denilebilir. Dolayısıyla toplumsal belleğin oluşmasında sûfî hikayelerinin katkısı bir hayli fazladır. Böylesi etkin bir usûlde kadın konusunun nasıl işlendiğini tespit etmek hiç şüphesiz İslâm toplumunun şifrelerini çözümlemede fayda sağlayacaktır.

$\mathrm{Bu}$ kısa girişten sonra menkıbelerdeki kadın algısını örneklerle detaylandırmak fayda sağlayacaktır. Zira mevcut örneklerin çok olması da konunun mühim delillerindendir. Hikayelerin hem niteliği hem de niceliği ayrı ayrı önem arzetmektedir. Bu sebepten çalışmada her bir örnek detaylı bir şekilde zikredilmektedir. Sûfî hikayelerinde geçen kadın kahramanları; tarihî kimliği olan kadınlar ve hayalî karakterler şeklinde ikiye 
ayırmak mümkündür. Tarihte yaşadığı kesin olan, isimleri tespit edilmiş sûfî hanımların erkeklerle karşılaştırılmasından iki durum ortaya çıkmaktadır. Şöyle ki, bu hanımların erkeklerden üstün olduğu ya bizzat dile getirilmiş ya da erkek velîlerle diyaloglarında kadın velîler üstün gösterilmiştir. Konunun örneklerini şu şekilde sıralamak mümkündür.

\section{Menkıbelerde Geçen ve Tarihî Kimliği Olan Sûfî Hanımlar}

\subsection{Erkeklerden Üstün Oldukları Bizzat İfade Edilen Sûfî Hanımlar}

İbnü'l- Arabî marifete, muhabbete ermek için kadınlığın bir engel teşkil etmediğini, hatta abdallar içinde kadınların da olduğunu zikreder. (İbnü'l-Arabî, 2016, 6/206) İbnü'l-Arabî'nin çok sonraları dile getirdiği bu anlayış, tasavvuf tarihinin ilk dönmelerinden itibaren kabul görmüş bir yaklaşımdır. Nitekim Hz. Peygamberin hadisinde geçtiği üzere; Hz. Meryem, Hz. Asiye, Hz. Hatice ve Hz. Fâtıma kemal mertebesine ulaşmış hanımların başında gelir. (Buhârî, "Enbiyâ", 34, 48; "Fedâil-u Ashâbi'n-Nebî", 32; Müslim, "Fadâilu's-Sahâbe", 70) Bahsi geçen hadise dayanan sûfîler, gayret ve ezelî takdir neticesinde bir kadının erkek bir sûfîden daha üst makamlara çıkabileceği anlayışına sahiptir. Söz konusu iddiayı destekler mahiyetteki rivayetler şu şekildedir: Muhammed b. Sîrîn'in (öl. 110/728) k1zkardeşi ilk zahidelerden, muhaddis Hafsa bt. Sîrîn (öl. 101 /719) için Hişam b. Hasan "Ben Hasan-1 Basrî'yi İbn Sîrîn'i gördüm ama Hafsa'dan daha akıllı birisini tanımıyorum" demiştir. (İbnü'l-Cevzî, 1979, 4/26) Büyük velî Râbia el-Adeviyye (öl. 185/801) için anlatılan bir menkıbede de Salih Mürrî 'nin, "Bir kimse bir kapıyı durmadan çalarsa nihayetinde kapı ona açılır" şeklindeki sözüne Râbia, "Bu kapı ne zaman kapandı ki açılsın" diyerek cevap verir, şaşkınlığını gizleyemeyen Mürrî, "Acayip şey, erkek cahil fakat aciz olan kadın âlim" demekten kendini alamaz. (Attâr, 2002, 1/104) Şüphesiz bu çeşit karşılaştırmalara İslâm tarihinin ilk dönemlerinde de rastlamak mümkündür. Hz. Ömer hutbede, kadınlara mehir verirken ifrâta kaçılmaması gerektiğini söyler. Onu dinlemekte olan bir kadın itiraz eder: "Ey Ömer! Senin buna hakkın yok. Zira âyet-i kerimede Cenâb-1 Hak, 'Birisine yüklerle (mehir) vermiş olsanız bile, onun içinden bir şey almayın' (en-Nisâ 4/20) buyurmuştur" " der. Bunun üzerine Ömer, "Kadın doğru söyledi, Ömer yanıldı, herkes Ömer'den daha fakih" diyerek kadının ilmi karşısında hayretini izhar eder. (Nesâî, "Nikah", 66)

Horasan bölgesinin meşhur sûfîsi Fâtıma Nîsâbûrîye (öl. 203/818) hakkında da erkek sûfîlerin ağzından övücü ifadeler rivayet edilmiştir. Zünnûn Misrî'ye (öl. 245/859) "Gördüklerinin en üstünü kimdir?" diye sorulmuş, O da "Mekke'de karşılaştı̆̆ım bir kadından daha yücesini görmedim. Ona Fâtıma Nîsâbûrîye deniyordu. Kur'an'ın tefsiri konusunda hayret verici konuşmaları vardı" demiş ve bazı meseleleri ona danışmaktan çekinmemiştir. Aynı şekilde Bâyezîd-i Bistâmî (öl. 324/848) de "Hayatım boyunca bir erkek ve bir kadından başkasını görmedim. Gördüğüm kadın Fâtıma Nîsâbûrîye idi. Kendisine bahsettiğim her makama aşina idi" şeklinde sözlerle onun üstün fazîletini ikrar etmiştir. (Sülemî, 1993, 61) Basralı Muâviye'nin azadlısı Zecle el-Abide hakkında Said b. Abdülaziz, "Ne Şam'da ne de Irak'ta Zecle'den daha faziletli bir kimse görmedim" demiştir. (İbnü'l- Cevzî, 1979, 4/40) Aynı şekilde Ebû Süleyman Dârânî (öl. 215/830) de Ümmü Harun için, "Şam'da onun bir benzerini görmedim" der. (Sülemî, 1993, 64; İbnü'1- Cevzî, 1979, 4/ 304) Kadınlar hususunda bir diğer itiraf da Ebû Hafs Haddâd'dan (öl. 260/874) rivayet edilmiştir. Ahmed b. Hadraveyh'in (öl. 240/854) hanımı Ümmü Ali için, "Ahmed b. Hadraveyh'in hanımı Ümmü Ali ile karşılaşıncaya kadar kadınlarla konuşmaktan hoşlanmazdım. Allah'ın marifetini dilediğine verdiğini anladım" şeklinde itirafta bulunmuştur. (Sülemî, 1993, 76) Bu ifadeler karşılaştırma 
içermemekle beraber söz konusu hanım sûfîlerin kadın, erkek pek çok velîyi geride bırakarak zirveye ulaştıklarını göstermektedir.

Bir diğer rivayette de Nîşâburlu hanım sûfî Fahraveyh bt. Ali'nin (öl. 313/925) fazileti yine bir erkek sûfîyle karşılaştırılarak vurgulanmıştır. Fahreveyh'in eşi Ebu Amr b. Nüceyd (öl. 365/975) "Fahraveyh'in sohbetinden en az Ebû Osman Hîrî'nin sohbetinden yararlandığım kadar istifade ettim" diyerek (Sülemî, 1993, 80) onun sahip olduğu makama işaret etmiştir. H. IV. asırda Dameğan'da yaşamış hanım mutasavvıflardan Melike bt. Ahmet b. Hayyeveyh, eşiyle beraber gittiği hacda Şiblî (öl. 334/946) ile görüşmüştür. Şiblî Melike'nin eşine, "Sen erkeksin o da kadın, fakat O hal bakımından senden daha üstündür" diyerek hanım sûfîyi övmüştür. (Sülemî, 1993, 110)

Yukarıda geçen menkıbelerde kadın erkek ayrımı vurgulanmış olsa da hakikatte, gerçek tevhîd ehli sûfîler nezdinde erkek ve kadın ayrımına çok da iltifat edilmez. Zira mesele kadın veya erkek olmak değil "er" olabilmektir. Bu sıfat cinsiyetin çok ötesindedir. Kıyamet günü "Ey erler!" diye seslenildiğinde ilk önce Hz. Meryem'in öne çıkacağ rivayet edilmiştir. (Nahşebî, 1999, 91) Bâyezîd-i Bistâmî meşhur Horasanlı sûfî Ümmü Ali'nin kadın kıyafetinde bir er olduğunu söylemiştir. (Hucvirî, 1996, 220; Attâr, 2002, 1/344) Kuşeyrî'deki şu menkıbe erlik makamını tasvir etmektedir: Fütüvvet ehli bir zat; bir garibi ve onun fütüvvet ehli arkadaşlarını ziyarete gider. Yemek yendikten sonra bir câriye gelir ve ellerine su dökmek ister. Misafir, "Bizim mürüvvetimizde bir kadının erkeğe su dökmesi yoktur" diye karşı çıkar. Bunun üzerine orada bulunan fetâlardan biri, "Ben bu eve yirmi seneden beri gelip giderim bu su dökenin kadın mı erkek mi olduğunu bilmem" demiştir. (Kuşeyrî, 2017, 510) Aynı şekilde Attâr'da geçen - tarihî olarak karşılaşmaları mümkün görünmese de- Hasan-1 Basrî'nin (öl. 110/728) Râbia ElAdeviyye için söylediği şu sözde de erlik makamına atıf yapılmaktadır. Hasan-1 Basrî, "Yirmi dört saat Râbia ile birlikte olduk, tarikat ve hakikat üzerine konuştuk. Bu süre içinde ne benim aklıma erkek olduğum, ne de onun hatırına kadın olduğu geldi. Meclis bitip ayrılma zamanı geldiğinde onu muhlis, kendimi ise müflis buldum" der. ( Attâr, 2002, 1/101)

Neticede yukarıda zikredilen; kadınları öven, hatta erkeklerden de ileride olduklarını vurgulayan rivayetler tasavvuftaki pozitif kadın görüşünün birer yansımalarıdır.

\section{2. Erkek Velîlerle Muhaverelerinde Üstün Gelen Kadın Sûfîler}

Menkıbelerde kadın velîlerin, erkek bir velîden daha yüksek haller yaşayabileceği aralarında geçen konuşmalarla ortaya konmuştur. Hikayelerde kadın sûfîler, önde gelen erkek velîlere, tasavvuf yolunun hakîkatini öğretir tarzda cevaplar vermektedir. Schimmel'e göre bu şekil; erkekleri hayrete düşüren hazır cevap kadın hikayeleri, sadece İslâm dünyasına özgü değildir, sözkonusu hikayelerden yola çıkarak kadının İslâm'daki -dolayısıyla da tasavvuf düşüncesindeki- durumunu tespit etmek doğru netice vermeyebilir. (Schimmel, 1999, 18) Bunun yanında kadınlarla ilgili hususların "bir kadın bile böyle iken ..." ş̧eklinde bir alt mesajla aktarıldığı da görülmektedir. Nitekim İmam Gazzâlî hanım sûfîlerin takvâ ve zühdünü örnek göstererek erkeklere nasihat eder, kadınların dahi başardığı yüksek manevî halleri herhangi bir erkeğin kolaylıkla yapabileceğini, aksi halde erkeklerin kadınların gerisine düşme zilletine uğrayacağını belirterek, onları gayret etmeleri hususunda motive eder. (Gazzalî, trs, 4/414) Yine de kadının yüceltildiği sûfî menkıbelerinin olumlu etkisini gözardı etmemek gerekir. Nitekim bahsi geçen metinler bir kadının ne derece yüksek makamlara çıkabileceğinin açık delilleridir.

Sûfî hanımların özgüvenli tavırlarını kendilerine örnek aldıkları Hz. Âişe'ye kadar götürmek mümkündür. Hz. Peygamber'in; "Dininizin üçte ikisini bu Hümeyrâ'dan 
alınız" diyerek övdüğü (Aclunî, trs, 1/449) Hz. Âişe, uydurma hadislerle ilgili kararlı tutumuyla bu alandaki üstünlüğünü ortaya koymuştur. Örneğin; Ebû Hureyre Hz. Peygamber'den, "Kadın, eşek ve köpek namazı bozar" şeklinde bir hadis rivayet eder. Bunu duyan Hz. Âişe, "Bizi eşeklere ve köpeklere benzettiniz! Vallâhi ben Rasulullah'ın önünde yatarken onun namaz kıldığını gördüm" diyerek itirazda bulunur. (Buhârî, "Salât", 105; Müslim, "Salât", 270) Aynı şekilde Hz. Âişe kadının uğursuzluğuyla ilgili rivayetlere de şiddetle karşı çıkmıştır.

Yukarıda geçtiği üzere Hz. Âişe, ilmiyle muhataplarına üstün gelen örnek bir şahsiyettir. İbnü'l-Arabî onun güçlü karekterine atıfta bulunur ve bu gücü kadınlığından aldığına vurgu yapar. Ona göre Hz. Âişe ve Hz. Hafsa'yı konu eden ayetler bir kadının ne denli güçlü olduğunun delilidir. Zira Ayette "(Ey Peygamber'in Eşleri!) Eğer siz ikiniz Allah’a tövbe ederseniz, ne iyi. Çünkü kalpleriniz kaydı. Eğer Peygamber'e karşı birbirinize arka çıkarsanız bilin ki Allah onun yardımcısıdır, Cebrail de, salih mü'minler de. Bunlardan sonra melekler de ona arka çıkarlar." (et-Tahrîm 66/4) buyrularak, Allah Teâlâ iki kadına karşılık, Hz. Peygamberin yardımcısı olarak sırf kendini saymakla yetinmemiş; Cebrâil'i, melekleri, salih mü'minleri de eklemiştir. (İbnü'l Arabî, 2007, 2/67-68)

Kadın erkek münazaralarında, üstünlüğün en fazla vurgulandığg hanım sûfî hiç şüphesiz ilk büyük kadın velî Râbia el-Adeviyye'dir. Nesir ve manzum yazılmış sûfî menkıbelerinin usta kalemi Feridüddin Attâr, "Tezkiretü'l-Evliyâ" adlı eserinde ona geniş yer vermiş, kadın erkek hususundaki görüşlerini Râbia'nın menkıbelerine yansitmıştır. Nitekim ona göre hadiste "Allah sizin suretinize bakmaz" (Müslim, "Birr", 33) buyrulmuştur. Dolayısıyla amel, surete göre değil iyi niyete göredir. Kaldı ki evliyâ zümresinin bulunduğu makamda herkes tevhidde (ilâhî vahdette) fânî olmuştur. Şu halde tevhidde, "ben ve "sen" namına bir şey kalmamış olduğundan, "erkek" ve "kadın" ayrımından da söz edilemez. (Attâr, 2002, 1/95) Kadın - erkek meselesine vahdet penceresinden bakan Attâr, Râbia'yı çağdaşı erkek sûfîlerden üstün gösteren menkıbeleri rivayet etmekte bir beis görmemiştir. Öyleki, tabiînin büyüklerinden Hasan-1 Basrî dahi Râbia'yla muhaverelerinde onun bir adım gerisinde kalmaktadır. Maddî âlemde bir araya gelmeleri mümkün görülmese de ruhanî alemde yahut Attâr'ın muhayyilesinde karşı karşıya gelen Râbia ve Hasan-1 Basrî esasında zahidlik anlayışları itibariyle karşılaştırılmaktadırlar ve böylelikle Râbia'nın sevgiye dayalı zühd anlayışının üstünlüğü vurgulanmaktadır. Söz konusu rivayetlerden birinde; Râbia bir dağa çıkar, çevresinde toplanan vahşi hayvanlar ve geyikler onu seyrederken birden Hasan-1 Basrî çıkagelir. Hayvanların hepsi ürküp dağılır, Hasan buna bozulur ve Râbia'ya onunla ünsiyet ve ülfet eden hayvanların kendinden niye kaçtığını sorar. Râbia da "bugün ne yedin" diye sorar. Hasan İşkembe çorbası yediğini söyleyince, "onların işkembelerini (ciğerlerini) yemişsin senden nasıl ürkmesinler?" der. (Attâr, 2002, 1/100) Bir başka rivayette de Râbia Hasan'ı göz yaşlarını dışa değil, içe akıtması gerektiği hususunda uyarır. Öyle ki bu damlaların derununda bir derya haline gelmesi gerektiğini ve bu umman içinde gönlünü arayacak olursa da onu "Muktedir hükümdarların nezdinde" (elKamer 54/55) bulabileceğini söyler. Bu sözler Hasan'ın gücüne gitse de bir şey söylemez. (Attâr, 2002,1/100) Benzer minvalde bir menkıbede Hasan seccadesini Firat Nehri'nin üzerine serer ve namaz için Râbia'yı çağırır. Râbia'da seccadesini havaya serer ve onu davet eder. Sonra da "senin yaptığını bir balık benim yaptığımı ise sinek yapar, iş bu iki şeyin ötesindedir" diyerek meselenin aslını ortaya koyar. (Attâr, 2002, 1/100) Yine bir gün Hasan, "Eğer cennette bir nefes Hak'ın dîdârından mahrum kalacak olsam o kadar çok ağlar ve sızlardım ki Cennettekilerin tümü bana merhamet ederdi" der. Râbia da "Bu sözler güzeldir ama eğer dünyada iken Hak'ın zikrinden gafil kalındığ 
zaman aynı tarzda ağlanıp sızlanırsa bu hal ahirette öyle olunacağının nişanı olur, aksi halde bahsettiğin hal gerçekleşmez" diyerek mukabelede bulunmuştur. (Attâr, 2002, 1/102) Râbia'nın zahidlikteki üstünlüğü sadece Hasan-1 Basrî'yle kıyaslanmamış, bir rivayette Hasan-1 Basrî'nin yanında Mâlik b. Dînâr (öl. 131/748) Şakîk-i Belhî (öl. 194/810) de meseleye dahil olmuştur. Bir gün adı geçen erkek sûfîler ve Râbia, sıdk ve sâdık mevzuunu müzakere ederler. Hasan; "Mevlâsından gelen darbelere sabretmeyen davasında sâdık ve samimi değildir" der. Râbia "Bu sözden benlik kokusu geliyor" deyince, Şakîk; "Mevlâsından yediği darbelere şükretmeyen davasında sâdık değildir" der. Râbia bu açıklamayı da beğenmez ve "bundan daha iyi ifade edilmesi gerekir" der. Bunun üzerine Mâlik b. Dînâr, "Mevlâsından gelen darbelerden haz almayan dostunun açtığı yaradan zevk duymayan bir kimse davasında sadık değildir" der. Râbia onun tanımını da eksik bulur ve şöyle der: "Mevlâsını müşahadede ve muradını temaşada darbenin elemini unutmayan bir kimse, davasında sadık değildir ve bunda şaşılacak bir şey de yoktur. Çünkü Hz. Yûsuf'u müşahadeye dalan Misırlı Hatunlar yedikleri darbenin elemini (bıçakla kesilen ellerinin acısını) hiç duymamışlardı. Şayet bir kimse Hâlık'1 müşahade halinde bu vasıf üzere bulunursa bunda şaşılacak ne var?" (Attâr, 2002, 1/108)

Görüldüğü üzere Râbia sadece Hasan-1 Basrî'ye değil, zamanın önde gelen diğer sûfîlerine de üstünlük sağlıyordu. Bu sûfîlerden biri de Süfyân es-Sevrî'dir. (öl. 161/778) Süfyân Râbia'nın yanında ellerini kaldırarak, "Allah'ım senden selâmet istiyorum" diye dua eder. Râbia da, "Bilmez misin? Dünyadan selâmet eldeki dünyalığı terk etmektir. Sen ona bulaşmışken bu nasıl olur?" şeklinde karşılık verir. (Sülemî, 1993, 28; İbnü'l- Cevzî, 1979, 4/29; Câmî, 1995, 844-845) Yine bir gün Süfyân, Râbia'nın yanında "Ah! ne kadar hüzünlüyüm" der. Râbia'nın tepkisi sert olur; "Yalan söyleme. Vah! ne kadar kedersizim de, zira sen gerçekten hüzünlü olsaydın hayattan bir lezzet alamazdın" demiştir. (İbnü'l-Cevzî, 1979, 4/29; Attâr, 2002, 1/104) Bir başka rivayette Süfyân hasta olan Râbia'ya iyileşmesi için dua etmesini öğütler, Râbia, "Bilmez misin ki izdırap çekmemi Hak Teâlâ irade etmiştir. Sen onun irade ettiği şeyin aksini dilememi istiyorsun, sevgilinin iradesine muhalefet reva mıdır?" der. Sonrasında Süfyân'ı hadis ilmiyle uğraştığı için, "Şayet dünyayı seven bir kişi olmasan ne iyi bir adam olurdun" diyerek, eleştirir. Râbia'nın sözleriyle üzülen Süfyân, "Ya Rab! benden razı ol" deyince Râbia, "Kendisinden razı olmadığın bir Zat'ın senden razı olmasını dilerken hiç utanmaz mısın?" sözleriyle iddiasını sürdürür. (Attâr, 2002, 1/107)

Sûfî menkıbeleri ve sözleri birden fazla kişiye isnad edilebilmektedir. Râbia'nın başkalarından yardım talep etmesini tavsiye edenlere verdiği cevap, (Attâr, 2002, 1/106) Ümmü Hassan için de rivayet edilmiştir. Ümmü Hassan'ın, ona amca oğullarından yardım talep etmesini söyleyen Süfyân es-Sevrî'ye cevabı oldukça nettir: "Ey Süfyân sen bu ana kadar benim gözümde büyük ve kalbimde önemli biri idin. Ben dünyayı onun sahibinden istemiyorum kaldı ki ona sahip olmayandan isteyeyim." (İbnü'l-Cevzî, 1979, 3/188; Câmî, 1995, 849) Şüphesiz zahidliğin en önemli göstergesi dünyadan nefret etmek değil ona karşı ilgisiz olmaktır. Riyâh Kaysî, Salih b. Abdül Celil, Kilâb, Râbia'nın yanına giderler ve dünyadan bahsedip onu kötülerler. Râbia ise onlara "Bakıyorum da dünyayı çok seviyorsunuz" der, adı geçen sûfîler şaşırır, nereden bu kanıya vardığını sorarlar. Râbia da, "Kalbinizde olmazsa onu anmazdınız" der. (Gazzalî, trs, 3/207; İbnü'l-Cevzî, 4/28)

Şüphesiz Râbia'nın üstünlüğünü vurgulayan en çarpıcı menkıbe İbrâhim b. Edhem'le (öl. 161/778) olandır. İbrâhim b. Edhem her adımda iki rekat namaz kılarak on dört yılda Mekke'ye ulaşmış, ancak Kâbe'yi yerinde bulamamıştır. Nedeni ise Kâbe'nin Râbia'yı karşılamaya gitmesidir. Bu durumu kıskanan İbrâhim, "Ya Râbia şu cihana 
saldığın velvele ne böyle!" diyerek ona çıkışır. Râbia, "Cihana velvele ve fitne salan sensin Kâbe'ye vasıl olmak için on dört sene bekledin. Sen namazla katettin ben niyazla" sözleriyle cevap verir. (Attâr, 2002, 1/99-98)

Attâr tüm anlattıklarına rağmen tatmin olmayan zahir ehlinin kadın hususundaki iddialarına yine Râbia'nın dilinden cevap verir: Bir cemaat Râbia'ya gelip, "Bütün faziletler erkeklere verilmiş, mürüvvvet tâcı, keramet kemeri erkeklerdedir. Hiçbir kadına nübüvvet gelmemiştir sen bu sözleri nereden söylüyorsun?" dediklerinde Râbia; "Söyledikleriniz doğru ama bencillik, kendini beğenme, kibir ve 'Ben sizin en yüce Rabbinizim' (en-Nâziât 79/24) iddiası da katiyyen herhangi bir kadından sadır olmamıştır. Ayrıca kadınlardan muhannes (kadınlaşmış erkek) olan da yoktur" şeklinde cevap vermiştir. (Attâr, 2002, 1/106) Neticede kadın konusunda Attâr'ın yaklaşımı sahip olduğu vahdet anlayışını yansıtmaktadır ve bununla birlikte hakkaniyetli, gönül alıcı ve oldukça latiftir. Mevlânâ'nın da; "Peygamber dedi ki, 'Kadınlar akıllı kişilere, ehl-i dil olanlara fazlasıyla galip olurlar. Fakat cahiller kadına galebe ederler' Çünkü onlar sert ve kaba muâmeleli olurlar" (Mevlâna, 1991, 1/195) sözleriyle belirttiği gibi kadının değerini ancak Attâr gibi edebî inceliklere hâiz bir erkek layıkıyla takdir edebilir.

Fâtıma Nîsâbûrîye'de de benzer tavrı görmekteyiz. Fâtıma, Zünnûn'a bir hediye gönderir, Zünnûn'da bu hediyeyi, "Hatunlardan bir şey kabul etmekte zillet ve kusur vardır" diyerek, iade eder. Bu durum karşısında Fâtıma, Zünnûn'a yolun inceliklerini hatırlatarak, "Gerçek sûfîler (verenle alan) arasında vasıta görmezler" demiştir. (Sülemî, 1993, 61; İbnü'l-Cevzî, 1979, 4/124; Câmî, 1995, 849) Benzer rivayete Abdü'l-Vahid Seyyarî'nin (öl. 375/985) hanımı Âişe bt. Ahmed Tavil Merveziyye'de de rastlamaktayız. O da kadınlardan hediye kabul etmeyi zillet olarak gören yaklaşımı ahmaklık olarak değerlendirmiştir. (Sülemî, 1993, 124)

İlk zahidler evliliği zühd hayatının engeli olarak görmüştür. Râbia el-Adeviyye'nin yaşamında da gördüğümüz bu yaklaşım sonraki dönemlerde yaygınlık kazanmamıştır. Oysa ki ilk zahidelerden Melike bt. el Münkeder'e "Bir erkekle evlensen de sana yardım etse" diye tavsiyede bulunulmuş, $O$ da, "Eğer Mâlik b. Dînâr ile Eyüp Sathiyanî karşıma çıksaydı düşünürdüm" demiştir. Karşısındaki kişi, "Işste ben Mâlik b. Dînâr'ım bu da Eyüp Sathiyanî" deyince Melike; "Üf size! ben de Allah'ın zikri sizi kadınları zikretmekten alıkor sandım" demiş ve namaza durmuştur. (İbnü'l-Cevzî, 1979, 2/201) Râbia el-Adeviyye ile karıştırılan ve onun gibi Basralı olan Râbia Ezdiyye de Abdu'l Vahid b. Zeyd'in evlenme teklifini sert bir şekilde ret etmiş onu şehvet düşkünü olmakla suçlamıştır. (Sülemî, 1993, 54) Hâkime Dımeşkiye de Râbia Şamiye'nin (öl. 229/843) kocası Ahmed b. Ebü'l-Havârî'yi ikinci kez evlenmek istediği için eleştirmiştir. Tepkisini, "Bir insanın gönlünü Hak'tan ayırarak iki kadına vermesi nasıl kabul edilebilir?" sözleriyle ifade etmiştir. (Câmî, 1995, 811)

Zahidelerden evli olanlar da zahitlikleriyle eşlerinin bir adım önünde gösterilmiştir. Ebû Abdullah Berâsî'nin hanımı Cevhere Berasiye, Riyâh Kaysî'nin hanımı Züâbe, Habib Acemî'nin (öl. 115/ 733) hanımı Amra gibi isimler gece ibadeti hususunda eşlerini uyardıkları rivayet edilmektedir. Hâtim Esam'ın (öl. 237/851) karısı da rızkın sahibi hususunda eşini tenkit eder. Rivayete göre Rûm topraklarına gazaya giden Hâtim Esam, eşine ne kadar nafaka bırakması gerektiğini sormuş karısı, "Hayatımı idame ettirecek kadar" demiş. Hâtim, "Senin hayatını idame ettirmek benim elimde değil ki" deyince karısı, "Peki benim rızkım senin elinde mi ki?" demiştir. Daha sonra bu hanıma kocasının ne kadar nafaka bıraktığı sorulduğunda, "Hâtim de benim gibi rızık yiyendir. Rızık veren burada bir yere gitmedi" şeklinde cevap vermiştir. (Attâr, 2002, 1/295) 
Erkek sûfîleri eleştirmekten çekinmeyen hanım sûfîlerden biri de Fâtıma Dımeşkiye'dir. Dımeşk Camii'inde konuşma yapan Ebû'l Hüseyin el-Malikî'ye, "Güzel konuştun, güzel de susuyor musun" diyerek az konuşmanın zahitlikteki önemine değinmiştir. (Sülemî, 1993, 94) Kureyşiye Neseviye de kendine "sus" diyen Ebu'l Kasım Nasrabazî'ye, "Sen sus ki ben de susayım" demiş ve sözlerinin güzel, ancak ahlakının kötü olduğunu yüzüne söylemekten çekinmemiştir. (Sülemî, 1993, 105) Bu şekil örnekleri çoğaltmak mümkündür.

\section{Menkıbelerde Geçen Efsanevî Karekterdeki Sûfî Kadınlar}

Tasavvufta anlaşılması zor metafizik hususlar hikayeler aracılığıyla somutlaştırılıp herkesin anlayacağı bir forma kavuşturulur. Sûfîlerin sıklıkla başvurduğu şiir, hikaye gibi edebî türler, tasavvufî bilginin geniş halk kitlelerine ulaşmasını sağlayan araçlardır ve sûfîler ilk dönemlerden itibaren güzeli, güzel usullerle anlatmayı tercih etmişlerdir. Hikaye, kıssa usulünü tercih edenlerin ilklerinden biri de Zünnûn Misrî'dir. (Schimmel, 2001, 64) Zünnûn, marifet, muhabbet gibi tasavvufun en müşkül hususlarını kimi zaman bir dağ başında ya da bir sahilde, harabede karşılaştığı kadın kahramanların dilinden aktarır. Bahsi geçen hanımlar Râbia el-Adeviyye'nin hikayesinde olduğu gibi genellikle câriyelerdir ya da yaşıı, kimsesiz hanımlardır. Zünnûn mesajını çoğu zaman böylesi kadınların dilinden ifade etmekle, muhatabının dikkatini daha ziyade çekmeyi amaçlamaktadır. Taşköprülüzade'nin de belirttiği gibi manevî, mücerret konuların, hissî bir tarzda anlatılması gerekir. Böylelikle mücerret hususlar menkıbeler aracılığıyla zihne iyice yerleşir. Zünnûn'a yolun hakikatini öğreten sufî hanımların hikayelerinden bir kaçı şu şekildedir: Zünûn, Kabe'yi tavafı esnasında bir câriyenin, "İlâhi beni sevmen hürmetine beni bağışla" dediğini duyar ve câriyeye, "Seni sevmem hürmetine demen daha doğru olmaz mı?" der. Câriye de, "Ey Zünnûn çekil başımdan, bilmez misin? Allah'ın öyle kulları vardır ki onu sevmelerinden önce O onları sever, Cenab-1 Allah'ın 'Allah bir topluluk getirecektir ki onları sever, onlar da O'nu sever' (el-Mâide 5/54) kelamını işitmedin mi?" diyerek, esrarengiz bir şekilde kaybolur. (İbnü'l-Cevzî, 1979, 4/417; Câmî, 1995, 861-863) Söz konusu menkıbenin farklı versiyonları kaynaklarda tekrar edilmiştir. Bir başka rivayette Zünnûn'a harap bir kilisede yaşayan âbide bir câriyeden sözedilir. Zünnûn onu görmeye gider ve selamlaşırlar, câriyeye, "Ey câriye Hıristiyanların meskeninde mi yaşıyorsun?" der. Câriye de "Başını kaldır bak, iki cihanda Hak Teâlâ'dan başka varlık görebilecek misin?" diye cevap verir. Zünnûn'un "yalnızlıktan sıkılmaz mısın?" sorusuna, "Benden uzak dur! Çünkü O'nun hikmetindeki güzellik ve muhabbetindeki tatlılık işte beni böyle bir pir eyledi. Ona kavuşma arzusu beni öylesine kapladı ki gönlümde ondan başkasına hiç yer yok" şeklinde yanıt verir ve Zünnûn'un isteği üzerine ona nasihatta bulunur. (Camî, 1995, 863) Benzer usulde bir başka menkıbede de Zünnûn, Antakya dağlarında, üzerinde yün cübbe olan Mecnûn bir câriye ile karşılaşır, onunla selamlaşır. Câriye, "Sen Zünnûn Mısrî değil misin?" diye sorar. Zünnûn, "Beni nasıl tanıdın?" deyince câriye, "Seni dostun dostu sevmesi marifetiyle tanıdım" der ve ona, "Cömertlik ne demektir?" diye sorar. Zünnûn da "Vermek, ihsan etmektir" der. Kadın, "Bu dünyadaki cömertliktir, dindeki cömertlik nedir?" şeklinde sorusunu yenileyince Zünnûn, "Allah'a itaate koşmaktır" der. Kadın Zünnûn'un cevabını eksik bulur ve "Allah Teâla'ya itaate koştuğun zaman O'nun da senin kalbine bakıp O'ndan başkasını istemediğini görmesidir. Yazıklar olsun sana Ey Zünnûn! ben yirmi yıldır ondan gönlümün arzuladığı bir şey istemiyorum. Ücret karş1lı̆g çalışan iş̧̧i konumuna düşerim diye korkuyorum. Ben ancak onu yüceltmek için çalışıyorum" ifadeleriyle meselenin aslını açıklar. (Camî, 1995, 863) Benzer bi menkıbede de Zünnûn çölde zenci bir câriyeye rastlar ve câriye ona adıyla hitap eder. Zünnûn câriyeye adını nerden bildiğini sorduğunda ise "Ey tembel! Allah Teâlâ cesetleri yaratmadan iki bin y1 önce ruhları yarattı. Sonra onları arzın etrafinda 
dolaştırdı. Orada tanışanlar anlaştı, tanışmayanlar da anlaşmadılar. Benim ruhum da senin ruhunla o esnada tanıştı" (İbnü'l- Cevzi, 4/417) sözleriyle diğer câriyeler gibi Zünnûn'un marifet ve muhabbet görüşlerinin dile gelmesine aracilık eder. Muhabbet husunda anlatılan ve Hucvirînin, "Bu menkıbede hoş bir nükte ve remz vardır" dediği hikayede; Zünnûn, Mısır'a gitmek için Kudüs'ten yola çıkar, yolda üzerinde yün aba elinde asa olan yaşlı bir hanıma rastlar, Allah'tan gelip Allah'a gittiğini söyleyen bu hanıma Zünnûn para vermek isteyince yaşlı kadın; "Ey Zünnûn benim hakkımda tasavvur ettiğin o düşünceler aklının azlığından ve doğru çalışmamasındandır, ben Allah için iş yapıyorum ondan başkasından ücret almam. Ben ondan başkasına ibadet etmediğim gibi O'ndan başkasından da hiçbir şey almam" diyerek, Zünnûn'a çıkışmış ve yanından ayrılmıştır. Hucvirî'ye göre yaşlı kadının, "Ben Allah için iş yapıyor ve amel ediyorum" demesi muhabbetteki sıdkın delilidir. (Hucvirî, 1996, 199)

Zünnûn'la hayalî kadın kahramanların yer aldığı menkıbeleri daha da çoğaltmak mümkündür ancak meselenin izahında bu kadarı yeterli görülmektedir. Konumuz için önem arzeden husus menkıbelerde kadın kahramanların bir adım önde zikredilmesidir. Menkıbelerdeki öncelikli amaç, bu olmasa da bahsi geçen hikayeler bir kadının bazı konularda Zünnûn gibi bir velîden dahi üstün olabileceği alt mesajını içermektedir. Bununla birlikte Hz. Musa ve Hz. Hızır kıssası hatırlandığında, menkıbelerden; hazır cevap bu câriyelerin Zünnûn'dan üst makamlara sahip oldukları anlamının çıkarılamayacağı yönünde itirazda bulunulabilir. Nitekim Hz. Hızır sahip olduğu bilgi yönünden Hz. Musa'ya üstünlük gösterse de Hz. Musa'nın Allah katındaki değeri çok daha yüksektir. Dolayısıyla bu menkıbelerden hareketle, kadın sûfîlerin, erkeklerden daha üst makamlara ulaşabileceği iddia edilebileceği gibi sadece belli alanlarda onlara üstünlük sağladıkları sonucu da çıkarılabilir. Neticede önemli olan kadın sûfîler hususunda kullanılan olumlu uslup ve dildir.

Zünnûn dışında da isimsiz câriye hikayeleri oldukça fazladır ve İbnü'l- Cevzî SıfatüsSafve'sinde bölgelere göre kadın sûfîleri anlatırken o bölgedeki adı meçhul câriyelerin hikayelerine de yer verir. Bu hikayelerde de ağırlıklı olarak olumlu kadın imajı çizilmekte, onların zühd ve takvâdaki üstünlükleri vurgulanmaktadır. Örneğin Kûfeli bir kadın İbn Ebu Leylâ'nın torunlarından Abdurrahman'a hızlı Kur'an okuduğu için çıkışmış, "Ey Abdurrahman sen Hûd sûresini böyle mi okuyorsun? Ben altı aydır onun üzerindeyim onu bitiremedim" demiştir. (İbnü'1-Cevzî, 3/190)

\section{Sûfî Hikayelerinde Kadın Sembolizmi}

Erkeğin merkeze alınarak, erkek açısından kadının anlatıldığı halk hikayelerinde ve tasavvuf edebiyatının seçkin örneklerinde kadın kahramanlar genellikle nefsin, erkekler aklın sembolü olarak işlenmiştir. Aklın erilliği düşüncesini, Antik Yunan filozoflarından Platon'a kadar götürmek mümkündür. Sûfîlere göre nefs, insanın kötülüğe meyleden karanlık tarafıdır. Nefs, akıl ve irade ile kontrol altına alındığında, insana ruhanî kuvvetler hakim olur neticede insan kemâle erer. Ak1l kelimesinin müzekker, nefs kelimesinin müennes olması böylesi bir benzetmeye yol açmış olabilir. Her ne kadar Câmî, " Müenneslikten erişmez güneşe bir kusur / Müzekkerlik şeref vermez aya / Üstün olurdu tüm erkeklerden / Her kadın olsaydı ĕger bir Râbia" dese de tasavvuf edebiyatında; nefs, dünya ve kadın arasında bağ kurulmuş, hikaye ve şiirlerde bahsigeçen husus işlenmiştir. Bu yaklaşıma göre nefs, dünya ve kadının ortak noktası aldatıcı olmalarıdır. Mânevî yönden olgunluğa ermemiş bir erkeği ihtiraslı bir kadın nasıl buyruğu altına alırsa, hevasının peşinden giden bir kimseyi de nefsi -burada kastedilen nefs, nefs-i emmaredir- esir alır. Ayette de geçtiği üzere nefsin hevâsı; kadına, oğullara, altın ve gümüşe, bineklere, besili hayvanlara, bereketli ekinlere 
olabilmektedir. (Âl-i İmrân 3/14) Ayette tek tek sayılan ve kişiyi Allah'ın zikrinden alı koyan hususlar Kur'an'da "dünya hayatı" şeklinde ifadelendirilir ve onun bir oyun, eğlence olduğu, insanı aldattığı sıklıkla vurgulanır. Şüphesiz sayılanlar içinde erkeğin en çetin imtihanı, kadındır. Dolayısıyla da erkek merkezli yazılan metinlerde kadının aldatıcılığıyla ilgili malzeme bir hayli fazladır. Hikayelerde dünyanın aldatıcılığı da kadına benzetilerek tasvir edilir, öyle ki; görünüş itibariyle süslü, işveli, aşufte ve alımlı bir gelin gibi olan dünyanın üzerindeki incecik örtü kaldırıldığı zaman suratı buruşuk, kazma dişli, patlak gözlü yaşlı bir cadı olduğu görülür. (Uludağ, 1995, 25) İslâmî gelenekte bu tür hikayeler hiçbir zaman kadın düşmanlığına sebep olmamış, hikayedeki sembolik dil dikkate alınarak darb-1 meselin verdiği mesaj önemsenmiştir. Hıristiyanlıkta olduğu gibi cadı avına çıkılıp kadınlar diri diri yakılmamıştır. Malum olduğu üzere kadının aldatıcılığı Hıristiyanlıkta Hz. Havvâ'ya kadar götürülmektedir. Kur'an'da ise Hz. Havvâ ile ilgili bu şekil bir ifade bulunmamaktadır. Erkeğin aklı, kadının nefsi temsil etmesine sûfîler içinden de menkıbe aracılığıyla eleştiri getirilmiştir: Fazîletli bir hanım günahkâr bir erkeğe, "Erkekle kadın arasında akı1 nasıl taksim edildi?" diye sorar. O da "Kadına bir, erkeğe dokuz pay verildi" şeklinde cevap verir. Kadın, "Şehvet nasıl taksim edildi?" şeklinde sorunca, adam, "Kadına dokuz, erkeğe bir pay verildi" der. Kadın da "Biz o bir akılla dokuz şehvete galip ve hâkim iken, yazık ki siz dokuz akılla bir şehvete yenik düşüyorsunuz" diyerek tepkisini dile getirir. (Uludağ, 1995, 65) Hikayede vurgulandığ 1 üzere asıl mesele kadın ve erkek olmak değil, mevcut potansiyeli kullanabilmek ve güzel ahlaka sahip olmaktır.

Yukarıda da geçtiği üzere sembolik anlatımın kendine has dilini dikkate almamak, kadınlarla ilgili metinlerde kişinin çelişkiye düşmesine neden olacaktır. Örneğin Mevlânâ Mesnevî'sinde "Kadın Hak nûrudur, sevgili değil... Sanki Yaratıcıdır, yaratılmış değil!" (Mevlânâ, 1991, 1/195) sözleriyle kadını över. Aynı eserde anlattığı Bedevî ve karısı hikayesinde ise kötü, huysuz bir kadın portresi çizer. Hikayedeki kadın, geçim darlığından dolayı sürekli kocasına şikayette bulunur, kocası da onu sabra ve tevekküle davet eder. Neticede hikayeyi yorumlayan Mevlânâ; karı kocadan kastın nefis ve akıl olduğunu, bu ikisinin (akıl ve nefs ) şu toprak evde (bedende ) gece gündüz birbiriyle savaştığını söyler. Hikayenin sonunda kadın, erkeğe tabi olur yani nefis, aklın kontrolüne girer. (Mevlânâ, 1991, 1/210) Görüldüğü üzere sembolik dilde asıl olan mânâdır. Bu hususu yine Mesnevî'den şu örnekle açıklamak mümkündür: Mevlânâ Mesnevî'nin birinci cildinde yer verdiği kurt, tilki ve aslanın hikayesinde tilkiyi; kurnazlık şeklinde de nitelendirilebilecek akıllılık ve ibret almanın sembolü olarak kullanır. Mesnevî'nin dördüncü cildindeki aslan, tilki ve eşek hikayesinde ise tilki hilekar, aldatan bir varlıktır. Bu hikayelerden hareketle tilkiyi, aklın sembolü olarak gösterdiği için Mevlânâ'yı tilkileri seviyor ya da tilkiyi aldatmanın, riyânın sembolü olarak gördügü için tilkilerden nefret ediyor şeklinde nitelendirmek doğru olmaz. Neticede Mevlânâ hikayedeki kişilerden hareketle değil de hikayenin ahlakî, irfanî mesaj1 hususunda irdelenebilir. (Meşhedî, 2006, 59) Esasında sözkonusu hususu Mevlânâ şu sözlerle açıkça zikreder: "Ey kardeş! hikaye bir ölçü kabı gibidir. / Mânâ ise içindeki dane misalidir/ Akıllı adam mânâ danesini alır/ Ölçü kabı var mı yok mu bakmaz!" (Mevlana, 1991, 2/278)

Attâr'ın anlattığı Şeyh-i San'ân hikayesi de öldü sanılan nefsin, ansızın dirilebileceğini göstermesi açısından ilginçtir. Hikayede takvâ sahibi, âlim, ârif bir şeyh, Hıristiyan bir kıza aşık olur ve aşk1 uğruna Hıristiyanlığı kabul eder, şarap içip, domuz çobanlığ 1 yapar. Müridlerin duasıyla Şeyh bir süre sonra eski haline döner. Olanları hayretle izleyen kız etkilenir ve müslüman olur, Allah'a öylesine aşık olur ki kısa bir müddet zarfında sararıp solar fani dünyadan göçüp Hak'a ulaşır. (Attâr, 1990, 1 /97-127) Görüldüğü üzere hikayede genç kızla remz edilen nefs, şeyhi buyruğu altına alır. Şeyh 
sarhoş olur yani aklın etkisinden çıkar, insandaki kötü vasıfları temsil eden domuzlara çobanlık yapar. Sonrasında şeyhin dönüşümüyle nefs etkisini yitirir ve ruhânileşir.

Leylâ ile Mecnûn mesnevîlerinde olduğu gibi tasavvuf edebiyatının manzum eserlerinde kadın ilahî aşka giden yolda bir araç olarak işlenmiştir. Nefs de kişiyi Allah'a ulaştıran en güçlü vasıtadır. "Eğer nefis olmasaydı hiç kimse Allah'a giden yolu kat edemezdi" denilmiştir. Zira nefs aşağı ve yukarı hareket kabiliyetine sahip olduğundan insanın eğitilebilen tarafıdır. Kişi esfel-i sâfilîn veya ahsen-i takvîm seviyesine nefsi aracılığıyla iner yada çıkar. Nefsin sıfatı öfke (gazab) ve şehvet (hevâ) dir. Hevâ yukarı doğru yöneldiğinde muhabbet ve aşka; gazab yukarı doğru yöneldiğinde gayret ve himmete dönüşür. Necmeddîn-i Dâye, gazab ve hevayı akbabaya benzetir ve nefis bunlara binerek yükseklere çıkar, der. (Dâye, 2013, 180) Dolayısıyla Mecnûn, Leylâ'dan Mevlâ'ya yol bulmuştur.

Bilindiği üzere sembol dilinin hakim olduğu bir diğer alan rüyalardır. Sûfîler rüyada görülen hayvanları -ki çoğunluğu vahşi hayvanlardır- ve kadını, nefs ve nefsin sıfatları olan gazab ve hevâ şeklinde tâbir eder. Nefs-i emmâre mertebesinde, rüyada görülen hayvanlar ve kadın, sâlikin kötü ahlakına ve fiskına delâlet eder. (Usta, 2019, 283) Sâlik nefs mertebelerinde ilerledikçe sembollere verilen anlamlar değişir, örneğin mutmainne makamında kadın görmek olumsuz anlam içermez.

Sûfîler sadece nefs mertebelerinin en alt tabakası nefs-i emmâre için kadın sembolü kullanmamış, nefsin en üst mertebesi nefs-i kâmile için de kadınlardan temsil getirmiştir. Kur'an'da övgüyle söz edilen Hz. Meryem, nefs-i kâmile olarak remz edilmiştir. Nitekim Yûsuf ile Züleyhâ kıssalarında Züleyhâ, nefsin en alt mertebesi emmâreden, mutmainne noktasına ulaşmaktadır. Bahsi geçen husus Kur'an'da açıkça belirtilmese de tasavvuf edebiyatında yaygın olarak bu şekilde işlenmiştir, dolayısıyla sûfî şairler, nefsin tekamülünü bir kadın vasıtasıyla anlatmayı tercih etmişlerdir.

Kadının nefsin sembolü olarak kullanıldığı meşhur mesnevilerden biri de Salâmân ü Ebsâl'dır. Lamiî Çelebi, Molla Câmî'den rivayet ettiği bu mesnevîde adı geçen kahramanların neleri temsil ettiklerini bizzat kendi açıklar. Kadın kahraman Absâl, nefsin şehvet boyutunu ve bedenin hazlarını remz eder. Erkek kahraman Salâmân cisimle ilgisi olmayan ruhtur. Salâmân'ın babası padişah, akl-1 evveli temsil eder. İki sevgilinin kaçarken binbir güçlükle geçtikleri deniz "hayvanî şehvetler ve nefsani lezzetler denizidir". Salâmân ve Absâl'ın içine atladıkları ateş maddi varlığı yakıp kül etmek için çekilen sıkı riyâzettir. Absâl ateşte yok olur ve Salâmân sağ kurtulur, ancak Absâl'ı unutamamaktadır. Salâmân Absâl'ı geri döndüreceğini vadeden hükümdarın danışmanının eğitimine girer, kırk günlük eğitimden sonra ona ebedî güzelliğin timsali olan Zühre gösterilir ve Salâmân Zühre'ye aşık olur böylece şehevî aşktan kurtulur. (Uludağ, 1997, 76-77) Görüldügüü üzere bu hikayede kadın hem nefsin, şehvetin hem de mutlak güzelliğin temsili olarak işlenmiştir. İslâm tasavvufunda Celâl ve Cemâl şeklindeki tecelliler içinde kadın daha ziyade Cemâl sıfatlarının tecellisi olarak kabul edilir. Kadındaki güzellik erkek için bir imtihandır. Erkek mutlak güzelliğin yansıması bu Cemâle (kadına) esir olabilir. Ancak hakikat üzere yaşarsa bu Cemâl (kadın) onu hakiki güzelliğe görürür. (Kılıç, 2013, 108) Kadını bu yönleriyle işleyen bir diğer meşhur mesnevî Şeyh Galib'in, Hüsn ü Aşk mesnevîsidir. Mesnevîde kadın karakter Hüsn, hüsn-ü mutlak'ı (Allah) temsil etmektedir. Erkek kahramanın adı Aşk'tır ve sâliki remzeder. Hüsn ve Aşk'ın yolculukları sırasında karşılaştıkları ve Aşk'ın ilk gördüğünde Hüsn zannettiği Çin padişahının kızı Hûşrüba, nefs olarak sembolize edilmiştir. (Okçu, 1999, 19/30) 
İbnü'l-Arabî, Hz. Peygamberin; "Bana dünyanızdan üç şey sevdirildi; kadın, güzel koku ve gözümün nuru kılınan namaz" hadisine (Nesâ̂,, "İşretü'n-Nisâ", 1) fazlaca önem verir. İbnü'l-Arabî'ye göre kadını sevmek Tanrı'yı sevmenin bir parçası veya O'na ulaştıran ve O'nu anlamayı mümkün kılan bir vasıtadır. (Demirli, 2013, 284-285) Tanrı bilgisinden önce kişinin kendini bilmesi doğrudan kadın-erkek ilişkisiyle bağlantılıdır. Erkek kadın aracılığıyla; kadın da erkek aracılığıyla kendini tanır (Demirli, 2013, 280) ve bu farkındalık hali onu mârifetullaha ve muhabbetullaha ulaştırır. Bu sebepten Mecnûn, Leylâ aracılığıyla, Züleyhâ da Yûsuf vesilesiyle ilahî marifete ve muhabbete ermiştir. İbnü'l- Arabî bu durumu Âdem-Havvâ ilişkisiyle açıklar. Tanrı insan ilişkisi fâil-münfail ilişkisiyle sınırlıdır. Âdem yaratmada fâil /etken olduğunu, kendinden var edilen Havvâ sayesinde idrak eder. Âdem kendindeki "fâil olma" gücü sayesinde Tanrının kendini var etmesini anlayabilirken, kendini de münfail/edilgen olarak tanır. (Demirli, 2013, 281) Kadının münfail olması onu ikincil bir seviyeye düşürüyor gibi gözükse de esasında varlıkta münfaillikten başkası yoktur ve varlık bütünüyle dişidir. Zât, cevher, ilk ilke yani illet-i ûlâ dişidir. İbnü'l-Arabî 'ye göre dişilik kozmolojik bir mertebedir. Ona göre; her kim ki dönüşüm ve oluşum yeri ise er de olsa dişilik mertebesindedir. Binaenaleyh kainatta her mahluk ontolojik ve irfanî düzeyde dişidir. (el-Hakîm, 2006, 34) Bu düşünceyle paralel olarak Bursevî, hakîkat-1 muhammediyye anlayışının gereği olarak Hz. Muhammed'in ümmiliğini onun bütün yaratılmışların anası olduğu şeklinde yorumlar. (Döner, 2014, 259) Esasında her varlık dişil ve eril prensipleri bünyesinde barındırmaktadır. İbnü'l-Arabî'ye göre erkeği kadından bir derece üstün kılan, onun kadından önce yaratılmasıdır. Nitekim fâil, münfailden önce gelir ve erkek, kadına göre fâil konumundadır. Erkek kadından önce var olduğu için de Allah'ı ondan önce idrak etmiştir. Bu da ona bir derece üstünlük sağlar zira evvelkine tezahür eden tecelli, sonradan gelene tekrar etmez. Çünkü Cenâb-1 Hakk aynı surette iki defa tecelli etmez. (el-Hakîm, 2006, 35)

Kadında fâillik, annelikle açığa çıkar, bu sebepten İslâm'da dolayısıyla da İslâm tasavvufunda annelik ayrı bir önemi haizdir. Şüphesiz annelik vasfı kadına pek çok mühim tecrübe kazandırır ancak anneliği ontolojik düzeyde önemli kılan, kadının kendini tanımada sahip olması gereken fâillik bilgisine ulaşmayı sağlamasıdır. $\mathrm{Bu}$ sebepten menkıbelerde takvâ ve zâhid annelere neredeyse Hz. Meryem derecesinde kutsallık atfedilmiştir. Örneğin, Ümmü Muhammed, oğlu Şeyh Abdullah b. Hafif'le Ramazan'ın son on gecesini evde ihyâ eder. Kâdir gecesi oğlu damda ibadet ederken Ümmü Muhammed evin içindedir ve ansızın Kadîr gecesinin feyz ve nûru zahir olur. Ümmü Muhammed oğluna; "Muhammed, yavrum neredesin? Senin orada aradığın şey buradadır" diye seslenir. Oğlu aşağı inip parıldayan nurları görünce validesinin ayaklarına kapanır. (Câmî, 1995, 852) Şüphesiz Hz. Meryem'in kemâlinde de annelik vasfının etkisi gözardı edilemez. İnsanlık tarihinde "ataerkil" aile düzeninden önce, "anaerkilliğin" ilk aile şekli olduğunu savunan araştırmacılar vardır. İlk çağlarda bazı toplumlarda; insan hayatının kaynağı olması, doğurganlığ1 ve verimliliği sebebiyle kadın ilahlaştırılmış, tabiatla olan benzerliği sebebiyle tabiatın sembolü sayılarak bereket tanrıçası veya anatanrıça kültü oluşmuş, neticede; Kybele, Artemis, Demeter, Astarte, Isis, Afrodit veya Venüs adlarıyla kişileştirilerek tapınma konusu olmuştur. (Harman, 2001, 24/83)

Kadının erkekten varedildiği anlayışına göre erkeğin kadına, kadının erkeğe olan arzusu, bütünün parçaya, parçanın bütüne olan meyli şeklinde açıklanmıştır. İbnü'lArabî'ye göre; Allah, Havvâ'nın çıkışıyla Âdem'in bedenindeki boşalan yeri arzu ile doldurmuştur, zira varlık boşluk kabul etmez. Böylece Âdem kendine olan sevgisi nedeniyle kadını sevmiştir. Çünkü Havvâ onun bir parçasıdır. Havvâ da Âdem'i kendinden çıktığı ve vücuda geldiği mekan olduğu için sevmiştir. Havvâ'nın sevgisi 
mebdeine olan sevgidir. Erkek ve kadının bir araya gelmesiyle ontolojik birlik hali yaşanmış olur, (el-Hakim, 2006, 34) Tanrı'ya ulaşmanın hazzı tadılır. Görüldüğü üzere İbn'ül-Arabî ve takipçileri kadına duyulan muhabbete ilahî bir boyut kazandırmış, böylelikle nesir ve nazım -özelikle mesnevîler ki yüzyıllarca hikaye geleneğinin en temel formu olmuştur (Tosun, 2017, 113)- tarzında sûfî aşk hikayelerinin yazılıp, yaygınlık kazanmasına vesile olmuşlardır. Mehmed Ali Aynî "Şeyh-i Ekber'i Niçin Severim?" adlı eserinde, şeyhin kadın muhabbetini, gayet ilahî ve çekici bir dille erkeklere öğretmesini ve öğütlemesini insanlık için büyük bir hizmet saymaktadır. Aksi halde muhabbet, tüysüz parlak yüzlü oğlanlardan misaller getirilerek anlatılmaya devam edecektir ki söz konusu husus istismara açıktır. (Aynî, 2012, 146-147)

"Nefsini bilen Rabbini bilir" sözündeki "nefs" kelimesinin içerdiği anlam zenginliğinden dolayı zikredilen ifadeyi; "kendi özünü, hakikatini bilen, Rabbini bilir" ya da "nefs-i emmaresini bilen, terbiye eden Rabbini bilir" şeklinde yorumlamak mümkündür. Esasında kadın sembolü nefs kelimesinin bu her iki anlamını da karşılamaktadır. Şöyle ki, "kadın vasıtasıyla kendi varlığını anlamlandıran erkek Rabbini bilir" denilebileceği gibi "kendindeki ahlakî zafiyetleri gideren kişi bu yolla Allah bilgisine ulaşır" demek de mümkündür.

Kadının nefsin sembolü oluşu, kadın sâliklerin durumunu anlamada kafa karışıklığına sebep olabilir, zira akıllara şöyle bir soru gelebilir: Bu sembolizm müennes bir sâlike için ne anlam ifade etmektedir? Burada yapılan hata sembol ile sembolize edilen ya da nesne ile onda tecessüm etmiş nitelik arasında ayrımın yapılamamasıdır. Temel mesele kadın yada erkek olmak değil insandaki eril ve dişil niteliklerdir. (Murata, 2019, 846) Sachiko Murata'nın eserinde dile getirdiği gibi ying ve yang özellikler yada İslâm tasavvufundaki şekliyle Celâl ve Cemâl tecellileridir. İnsanın kemali için bu özelliklerin bir arada olması gerekir. Nitekim Allah'ın halifesi olarak yaratılan ve meleklerin kendine secde ettiği Hz. Âdem; "münferid ruh" yani henüz tefrik edilmemiş Âdem'dir ve bu haliyle ilahî olanın mükemmelliğini yansıtır. Hakîm, Kâdir gibi Celâl isimlerine ve Rahmân, Rahîm gibi Cemâl isimlerine sahip olması dolayısıyla, hem müzekker hem de müennes sıfat ve faziletleri ihtiva eder. Böylelikle ilk Âdem'in saflık haline ulaşmak için insan, müzekker ve müennes tüm faziletlere sahip olmak durumundadır. İnsanın cesur, kuvvetli, cengaver olması yetmez ayrıca nazik, sakin, merhametli ve sadık olması da gerekir. Bu açıdan bakıldığında eğer yoldaki her kadın bir erkek (er) ise yoldaki her erkek de bir açıdan kadındır. (Dakake, 2014, 164) Neticede kadının sûfî sembolizmdeki durumu çok yönlü ele alınması gereken bir husustur.

\section{SONUÇ}

İslâm tasavvufunun kadın hususunda daha olumlu tavrının olduğu iddiasına sûfî menkıbelerinden deliller getirmek mümkündür. Zira bahsi geçen menkıbelerde zühd ve takvâ sahibi hanımların faziletleri cömertçe sergilenmektedir. Bununla da yetinilmeyip erkek sûfilerle aralarında dramatize edilen sahnelerde başrol yine kadın kahramanlara verilmektedir. Öyle ki, bu hikayelerde tasavvuf tarihinin önde gelen erkek sûfîlerini hayrete düşürüp, aciz bırakan son sözü kadın sûfîler söylemektedir.

Tasavvuf edebiyatının gelişmesiyle mesnevîler hikaye geleneğinin en temel formu olmuştur ve bu eserlerde kadın kahramanlar nefs ile remz edilmişlerdir. Sembol ile sembolize edilen ayrıştııılmadığında, bu hikayelerden kadının aşağılandığı sonucu çıkarılabilir ki, bu hatalı bir tespit olur. Nitekim sembol dilinde önemli olan verilmek istenen mesajdır. Kaldı ki sûfiler sadece nefsin alt mertebeleri için değil nefs-i kamile 
için de kadınlardan misal getirmişler, Hz. Meryem'i nefs-i kamilenin sembolü olarak zikretmişlerdir. "Nefsini bil" kadim öğretisi tasavvufta da önem arzetmektedir. İbnü'lArabî; Hz. Âdem ve Hz. Havvâ'dan yola çıkarak Âdem'in ancak Havvâ aracılığıyla kendini tanıyabileceğini bunun neticesinde de Rabbini bileceğini iddia eder. Dolayısıyla aşk hikayelerinin anlatıldığı mesnevîlerde kadın ilâhî muhabbete götüren bir vasıta olarak remz edilmiştir.

Tasavvufun Yeni Eflatunculuk etkisiyle felsefî bir boyut kazanmasıyla tasavvufta kadın konusu ontolojik düzeyde ele alınmıştır. Bu hususta özellikle İbnü'l-Arabî dikkat çeken bir isimdir ve söz konusu alanda, İbnü'l-Arabî ekseninde yapılacak yeni çalışmalara ihtiyaç vardır.

\section{KAYNAKÇA}

Attâr, Feridüddin. Tezkiretü'l-Evliyâ. 2 Cilt. çev. Süleyman Uludağ. İstanbul: Mavi Yayınc1lık, 2002.

Attâr, Feridüddin. Mantık Al-Tayr. 2 Cilt. çev.Abdülbaki Gölpınarlı. İstanbul: Milli Eğitim Basımevi, 1990.

Aynî, Mehmed Ali. Şeyh-i Ekber'i Niçin Severim?. sad. Rahmi Yananlı \& İsmail Dervişoğlu \& Emir Hüseyin Yiğit. İstanbul: Büyüyen Ay, 2012.

Câmî, Nûreddin Abdurrahman b. Ahmed. Nefehâtü'l-Üns min Hadarâti'l-Kuds. çev. Lâmî Çelebi. sad. Süleyman Uludağ \& Mustafa Kara. İstanbul: Marifet Yayınları, 1995.

Dakake, Maria Massi. "Allah Yolu Üzerinde Erler Gibi Yürümek". Aşk ve Hikmet Yolu Tasavvuf. ed. Jean Louis Michon vd. çev. Nurullah Koltaş. 155-175. İstanbul: İnsan Yayınları, 2014.

Dâye, Necmüddîn. Sûfilerin Seyri Mirsâdu'l-İbâd. çev. Hakkı Uygur. İstanbul: İlk harf Yayınevi, 2013.

Demirli, Ekrem. İbnü'l-Arabî Metafiziği. İstanbul: Sufî Kitap, 2013.

Döner, Nuran. Sûfilere Göre Hz. Peygamber. İstanbul: İnsan Yayınları, 2014.

el-Hakîm, Suad. "Kadının İbn Arabî'de İkili Tasavvuru". Sûfî Gelenek ve Hayat Keşkül 8 (2006), 30-36.

Fromm, Eric. Rüyalar, Masallar, Mitoslar (Sembol Dilinin Çözümlenmesi). çev. Aydın Arıtan \& Kaan Ökten. İstanbul: Arıtan Yayınevi, 1992.

Gazzâlî, Ebû Hamid Muhammed. İhyâu Ulûmi'd-Dîn. 4 Cilt. Beyrut: Daru'l-Marife, trs.

Goleman, Daniel. "Takdim" Toynak Sesini Duyunca Zebra Gelsin Aklina. mlf. Shems Friedlander. çev. Ömer Çolakoğlu. 9-12. İstanbul: Sufi Kitap Yayınları, 2019.

Harman, Ömer Faruk. "Kadın". Türkiye Diyanet Vakfi İslâm Ansiklopedisi. 24/82-86. İstanbul: TDV Yayınları, 2001.

Hucvîrî, Ebü'l-Hasen. Keşfü'l-Mahcûb Hakikat Bilgisi, çev. Süleyman Uludağ. İstanbul: Dergah Yayınları, 1996.

İbnü'l-Arabî, Muhyiddin. Fütûhât-ı Mekkiyye. çev. Ekrem Demirli. 17 Cilt. İstanbul: Litera Yayıncılık, 2016

İbnü'l-Cevzî, Cemâlüd-Dîn Ebu'l Ferec Abdurrahman. Sifatu's Safve. 4 Cilt. thk. Mahmud Fahurî \& Muhammed Kal'acî. Beyrut: Dâru'l-Marife, 1979. 
Kılıç, Mahmud Erol. Hayatın Satır Araları Modern Zamanda Kendini Bulmak. İstanbul: Sufî Kitap, 2013.

Kuşeyrî, Abdülkerim. Risaletü'l-Kuşeyriyye. thk. Enes Muhammed Adnan Şerfavî. Beyrut: Daru'l-Minhac, 2017.

Meşhedî, Mehdî Firdevsî-i. "Mevlânâ'nın Düşüncesinde Kadın". Şarkiyât Araştırmaları Dergisi. çev. Hasan Almaz. 6/20 (2006), 53-64.

Mevlânâ, Celâleddîn-i Rûmî. Mesnevî. 6 Cilt. çev. Veled İzbudak. sad. Abdülbaki Gölpınarlı. İstanbul: Milli Eğitim Basımevi, 1991.

Murata, Sachiko. İslâm'da Cinsiyet Diyalektiği İslâm'ın Taosu. çev. Şamil Öçal. Ankara: Hece Yayınları, 2019.

Nahşebî, Ziyâüddîn. Silku's- Sulûk Ariflerin Yolu. çev. Mustafa Çiçekler \& Halil Toker. İstanbul: İnsan Yayınları, 1999.

Okçu, Naci. "Hüsn ü Aşk". Türkiye Diyanet Vakfi Islâm Ansiklopedisi. 19/29-31. İstanbul: TDV Yayınları, 1999.

Schimmel, Annemarie. Ruhum Bir Kadındır. çev. Ömer Enis Akbulut. İstanbul: İz Yayınc1lık, 1999.

Schimmel, Annemarie. İslâmın Mistik Boyutları. çev. Ergun Kocabıyık. İstanbul: Kabalcı Yayınevi, 2001.

Sülemî, Ebu Abdurrahman. Zikru'n-Nisveti'l-Müteabbidâti's-Sûfiyyat. thk. M. Muhammed Tanâhî. Kahire: Mektebetü'l-Hancî, 1993.

Şahin, Haşim. "Menâkıbnâme". Türkiye Diyanet Vakfı İslâm Ansiklopedisi. 29/ 112114. Ankara: TDV Yayınları, 2004.

Tosun, Necip. Doğu'nun Hikâye Kuramı. İstanbul: Büyüyen Ay, 2017.

Uludağ, Süleyman. Sûfî Gözüyle Kadın. İstanbul: İnsan Yayınları, 1995.

Uludağ, Erdoğan. "Lami'î'nin Sâlâman u Absâl adlı Mesnevisi". Atatürk Üniversitesi Türkiyat Araştırmaları Enstitüsü Dergisi 8 (1997), 67-77.

Usta, Muhiddin. Tasavvuf Eğitimi Yöntemleri Etvâr-ı Seb'a / Yedi Mertebe. Ankara: Mânâ Ajans Yayınları, 2019. 